\title{
Research on the Concept of Hydrogen Supply Chains and Power Grids Powered by Renewable Energy Sources: A Scoping Review with the Use of Text Mining
}

\author{
Marzena Frankowska *(D), Krzysztof Błoński (D), Marta Mańkowska (D) and Andrzej Rzeczycki (D) \\ Institute of Management, University of Szczecin, 71-004 Szczecin, Poland; krzysztof.blonski@usz.edu.pl (K.B.); \\ marta.mankowska@usz.edu.pl (M.M.); andrzej.rzeczycki@usz.edu.pl (A.R.) \\ * Correspondence: marzena.frankowska@usz.edu.pl
}

check for

updates

Citation: Frankowska, M.; Błoński, K.; Mańkowska, M.; Rzeczycki, A. Research on the Concept of Hydrogen Supply Chains and Power Grids Powered by Renewable Energy Sources: A Scoping Review with the Use of Text Mining. Energies 2022, 15, 866. https://doi.org/10.3390/ en15030866

Academic Editors: Juri Belikov, Audrius Banaitis and Yuriy Bilan

Received: 22 November 2021

Accepted: 21 January 2022

Published: 25 January 2022

Publisher's Note: MDPI stays neutral with regard to jurisdictional claims in published maps and institutional affiliations.

Copyright: (C) 2022 by the authors. Licensee MDPI, Basel, Switzerland. This article is an open access article distributed under the terms and conditions of the Creative Commons Attribution (CC BY) license (https:/ / creativecommons.org/licenses/by/ $4.0 /)$.

\begin{abstract}
The key direction of political actions in the field of sustainable development of the energy sector and economy is the process of energy transformation (decarbonization) and increasing the share of renewable energy sources (RES) in the supply of primary energy. Regardless of the indisputable advantages, RES are referred to as unstable energy sources. A possible solution might be the development of the concept of hydrogen supply chains, especially the so-called green hydrogen obtained in the process of electrolysis from electricity produced from RES. The aim of the research undertaken in the article is to identify the scope of research carried out in the area of hydrogen supply chains and to link this research with the issues of the operation of electricity distribution networks powered by RES. As a result of the scoping review, and the application of the text-mining method using the IRaMuTeQ tool, which includes the analysis of the content of 12 review articles presenting the current research achievements in this field over the last three years (2016-2020), it was established that the issues related to hydrogen supply chains, including green hydrogen, are still not significantly associated with the problem of the operation of power grids. The results of the conducted research allow formulating recommendations for further research areas.
\end{abstract}

Keywords: hydrogen supply chains; green hydrogen; energy; power grids; renewable energy sources; scoping review; text mining; IRaMuTeQ; decarbonization

\section{Introduction}

Satisfying the growing demand for energy and reducing the negative impact of the energy sector on the environment and society are two interrelated and most important problems of the modern world [1]. The negative effects of climate change are a great challenge for the energy sector, which is subject to increasing political pressure to limit greenhouse gas emissions, in particular, carbon dioxide emissions [2,3]. The challenges that lie before a decarbonized energy sector are identified in relation to environmental sustainability, security of energy supply, economic stability, and social aspects [4-7]. This is reflected in the package of legislative proposals referred to as the European Green Deal adopted by the European Commission in July 2021, aimed at adjusting the European Union (EU) climate, energy, transport, and tax policy to the goal of reducing net greenhouse gas emissions by least 55 percent by 2030, as compared to the level achieved in 1990 . The assumptions of the European Green Deal are to contribute to the transformation of the EU into the first climate-neutral region of the world by 2050 [8-10].

The key direction of political actions in the field of sustainable development of the energy sector is the process of energy transformation (decarbonization) and an increase in the share of renewable energy sources (RES) in the primary energy supply [11,12]. RES technologies provide an excellent opportunity to mitigate greenhouse gas emissions and reduce global warming by replacing conventional energy sources based on natural resources [13-15]. Nevertheless, regardless of the indisputable advantages, RES are referred 
to as unstable energy sources, due to the dependence of produced energy volume on noncontrollable factors, such as weather or time of day $[16,17]$. The growing share of unstable RES in the energy mix has a number of consequences for the operation of power grids. As the number of RES-based electricity producers grows, the problem of unstable operation of power grids will increase, in particular in the area of distribution grids. Therefore, more and more attention is being paid to the issue of storing energy produced from RES in the context of stabilizing electricity distribution networks, with one of the solutions being the development of hydrogen technologies, in particular, those based on pure hydrogen (the so-called green hydrogen). Green hydrogen may play an increasing role in the process of decarbonizing the energy sector and is gradually becoming one of the key energy carriers used in the European Union [18].

The use of hydrogen technologies in RES stabilization in the context of the operational safety of electricity distribution networks requires both a comprehensive approach and strategic planning in line with the concept of designing a hydrogen supply chain that distinguishes the phases of supply, production, storage, and distribution of electricity $[19,20]$.

Research into hydrogen supply chains is still at an early stage of development. The aim of the research undertaken in the article is to identify the scope of research carried out in the area of hydrogen supply chains, and to link this research with the problems of the operation of electricity distribution networks powered by RES.

In order to achieve the research goal, the following research questions were formulated:

- To what extent does the research take into account the topics of hydrogen supply chains and the functioning of electricity distribution networks?

- To what extent does the previous research take into account the environmental aspect related to the growing share of RES and climate policy objectives?

The research used the Scoping Review (SR) methodology as a tool for aggregating knowledge through the process of mapping and structuring information provided by the literature review. Additionally, as a result of an exploratory test analysis using a textmining tool (IRaMuTeQ software, version 0.7 alpha 2, http:/ / www.iramuteq.org/ accessed on 22 October 2021), it was possible to demonstrate the current state of knowledge and identify research and cognitive gaps. Recommendations were also formulated for future research in the area of hydrogen supply chains in the context of energy transformation processes and the growing share of RES in primary energy production and the implications of these changes for the stable operation of electricity distribution networks.

The article consists of five parts. The first two parts present an introduction to the research topic and the background of the study. The third part describes the SR research methodology and the process of exploratory text analysis (IRaMuTeQ software). The fourth part presents the results of the lexicographic analysis and the analysis of similarity. The final part contains a discussion and conclusions from the research, together with a recommendation for further research.

\section{Background of the Study}

Among the theoretical achievements to date, individual phases of the functioning of hydrogen supply chains have been the subject of separate studies.

The first in-depth research on the hydrogen supply chain (HSC) was undertaken in 2008-2012. The subject of these studies was primarily the evolution of the hydrogen market, strongly related to transport. Four main components were distinguished in the structure of the hydrogen supply chain: hydrogen production subsystem, hydrogen storage subsystem, hydrogen transportation subsystem, and hydrogen refueling station subsystem [11]. The research focused on the infrastructure for the production and storage of hydrogen, as well as the means and processes of its transport [21]. These studies did not take into account the feedstock phase, which is currently considered an important component of HSC. In the first HSC structures, taking into account the supply phase, four nodes were identified [22]: suppliers of raw materials (local or international), production plants, 
storage points, and petrol stations. In this approach, however, the independence of research regarding individual phases of hydrogen supply chains is still visible.

In the latest research (post-2015), hydrogen is more and more often considered an energy carrier and a measure stabilizing the operation of power grids, while the production of hydrogen in the electrolysis process is regarded the optimal solution. Research focuses heavily on the strategic planning of the HSC and the deployment of hydrogen infrastructure. In the structure of HSC, more and more emphasis is being placed on the importance of the supply phase [23].

At the same time, independent in-depth research on each of the HSC phases is intensively developing, due to the existence of many options for their operation. In the supply phase (feedstock), RES (biomass, solar, and wind energy), and nuclear energy are increasingly being analyzed as sources of green hydrogen production $[24,25]$. Nevertheless, the structure of RES is often overlooked in research. At the same time, it is indicated $[26,27]$ that the art of sustainable use of grid-integrated RES has its roots at the pre-design stage, where appropriate reliability tests are required in order to determine the appropriate place to minimize transmission losses. Only a small number of studies also emphasize the importance of the availability of water as the main raw material in the electrolysis process, as well as oxygen, which is the key raw material in the coal or biomass gasification process [28,29]. In the HSC production phase, steam methane reforming (SMR), biomass and coal gasification (BG and CG, respectively), and finally electrolysis are the three main production technologies analyzed in the research. It is indicated that at present most of the hydrogen is produced using SMR, currently considered the cheapest production method [30]. Nevertheless, significant advantages of electrolysis have been pointed out for the future. Although these technology processes are more expensive, they allow wider use of hydrogen with a low carbon footprint in the energy system [31-33]. The hydrogen storage phase is considered a way to deal with plant downtime and fluctuations in energy demand, as well as a solution to the problem of balancing power grids due to the growing share of energy production from RES [34]. Most of these studies are focused on the technical and economic aspects of HSC design. In the distribution phase, the research focuses on the issue of hydrogen refueling stations [35]. The research also covers the issues of hydrogen transport and factors influencing the choice of hydrogen transport means [36], as well as the issues of social acceptance for the technological revolution based on hydrogen cells taking place in the motorization sector [37].

In terms of further research, it is indicated [38] that, inter alia, it should, to a greater extent, take into account the aspects related to the production of hydrogen from RES and the implications of the increase in the share of RES capacity for the operation of electricity grids. Electrolysis should be considered in the context of storing surplus energy generated from RES and balancing the operation of power grids [39].

The correlation between the functioning of energy supply chains and the hydrogen supply chain is presented in Figure 1.

Identification of the interdependencies of the functioning of energy supply chains with the hydrogen supply chain indicated in Figure 1 is the main subject of the research undertaken in this article.

\section{Methodology}

The study used the Scoping Review (SR) literature review method, which enables the mapping of literature from a given research area, in particular in terms of the main concepts, theories, types, and sources of knowledge [40]. This method is particularly useful in the literature review of broad areas of research [41] or in the initial stages of research [42], when the research area is not precisely defined and descriptions in scientific publications are dispersed [43]. Scoping Reviews identify research gaps through the selection and synthesis of existing knowledge [44,45]. They are also used to inform about research plans and to identify implications for policy or practice regarding decision making [46]. 
In the analysis of the collected research material, traditional techniques (in-depth study of the content of articles) and statistical text-mining techniques with the use of the IRaMuTeQ software were used. The main source of data on literature sources was the Web of Science Core Collection (WoS) database.

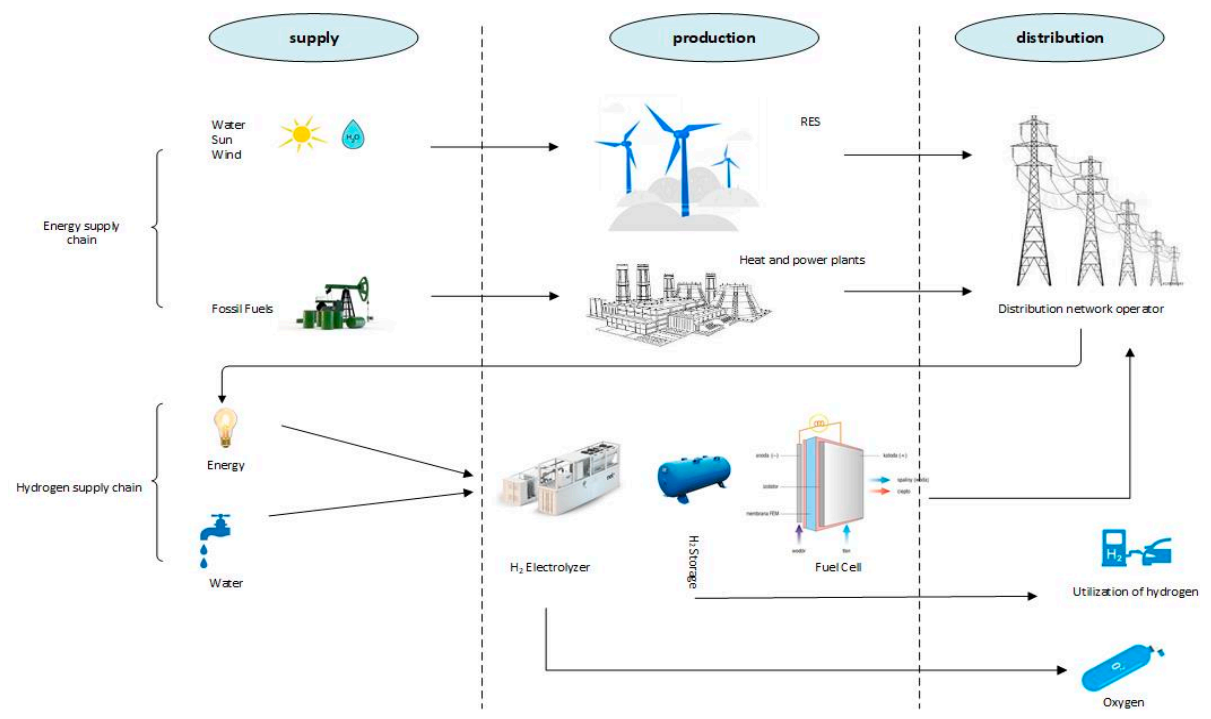

Figure 1. Energy supply chain cooperating with the hydrogen supply chain. Source: own elaboration.

In line with the adopted SR methodology, the literature review process included the following stages:

1. Formulating research question;

2. Identifying relevant sources;

3. Selecting research;

4. In-depth study of the research content using narrative technique and exploratory text mining using the IRaMuTeQ software;

5. Reporting test results.

In the first stage of SR, the main research question was formulated:

What do we know about the possibilities of stabilizing energy networks based on renewable energy sources using hydrogen technologies?

Based on this research question, the searching criteria for literature and qualifying literature for further analysis were established in the second stage. Three main keywords were designated: hydrogen, power grid, and renewable sources. The formulated keywords allowed for an initial selection of literature items based on titles and abstracts (screening 1). A three-stage search in the WoS database was conducted, which resulted in the identification of 479 literature references. From the selected database of 479 articles, 201 references that were not directly related to the research topic were rejected. For the most part, the subject of these articles was related to hydrogen vehicles, obtaining hydrogen from carbon captured from the air (CSS), and hydrogen batteries. Moreover, non-English language articles and articles without abstracts were rejected.

As a result, 278 articles were qualified for further analysis.

In the third stage of SR, another selection of research was made from the list of 278 articles for further analysis (screening 2). In order to minimize errors related to the omission of articles important for the purpose of the research, additional research questions were formulated:

- What do we know about renewable energy systems that use green hydrogen for energy storage?

- What do we know about methods and models for stabilizing energy networks based on hydrogen storage systems? 
- How do hydrogen supply chains that include a storage cell function?

- What factors are taken into account when identifying the locations of hydrogen storage facilities?

The formulated additional research questions were used to determine additional keywords that were included in the further stage of selecting articles in the WoS database: hydrogen, supply chain, storage, renewable sources, model, location, power grid, and electrolysis. The indicated keywords were cross-used in a four-step search. As a result, an additional 33 articles (after eliminating duplicates from the first search), strictly corresponding to the aim of the research and not identified during the first search, were obtained.

Finally, 311 articles from the WoS database were selected for the initial analysis of the full texts of articles, including:

- 197 original research;

- 1 book chapter;

- 76 conference proceedings papers;

- 37 review articles.

In the fourth stage of the research, from the selected list of 311 articles, 37 review articles were initially chosen. The choice of only review articles was dictated by the fact that such publications are the most comprehensive form of research synthesis in a given area. Review articles in accordance with the methodologies of a systematic literature review should be analyzed in the first place (before the original scientific articles). Moreover, the structure and descriptive nature of review articles (mostly text material) make them best suited for content analysis using text-mining tools (here: the IRaMuTeQ software). A selected group of 37 review articles was subjected to an in-depth analysis of the full content in terms of the adopted research objective. On this basis, from the list of 37 review articles, 12 articles that most closely corresponded to the research questions posed were selected. The articles were published in the period 2016-2020. The list of 12 selected review articles that include an overview of the current research results in the analyzed subject is presented in Appendix A.

The summary of the selection process of literature sources in the SR process is presented Figure 2.

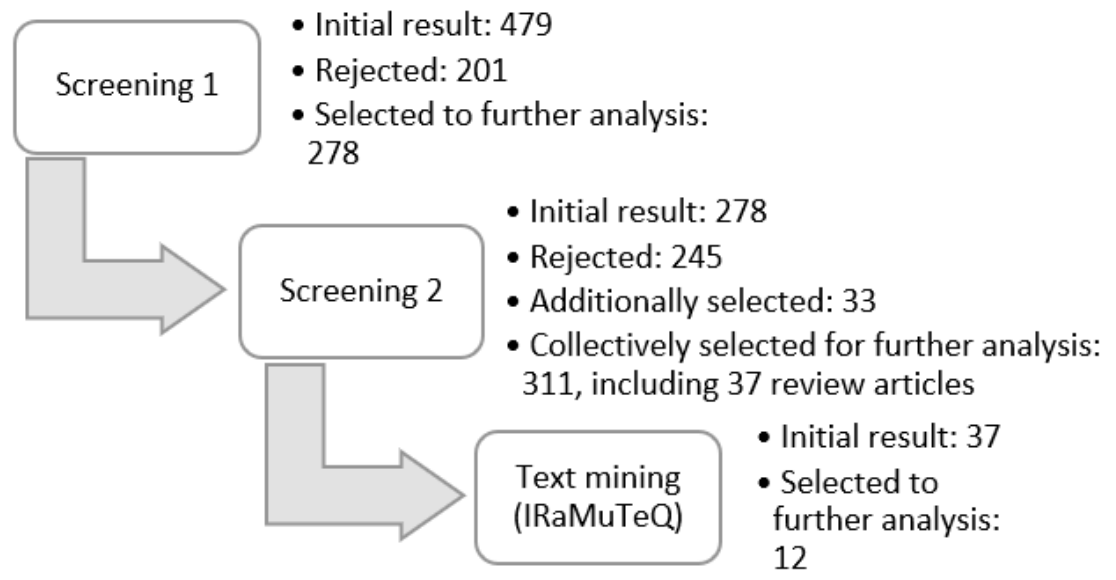

Figure 2. The process of selecting articles from the WoS database for text analysis using the IRaMuTeQ software. Source: own elaboration.

In the fifth stage of the research, a selected group of 12 review articles was subjected to the process of text mining. Exploratory text mining is a multidisciplinary field derived from data mining, information retrieval, data extraction, text categorization, and probabilistic modeling. It uses, among others, statistical methods or machine learning. The creator of the concept of text mining is Marti A. Hearst [47], who defined it as "a process aimed at discovering by computer of new, previously unknown information from written resources". 
The goal of a process defined in this way is to find relevant, previously unknown, and comprehensive knowledge from unstructured text data.

In line with the adopted methodology, the process of exploratory text analysis consisted of several phases [48]:

1. Text extraction (characterized in the first part of the methodology).

2. Text unification - the goal of this stage is to convert all documents to one consistent text format, as documents obtained from various sources may differ significantly from each other.

3. Transformation - the modification of a collection of texts into a form that enables further analysis.

4. Analysis of transformed texts.

Based on the process of exploratory text analysis presented above, individual activities were performed to present the obtained research results. The selected 12 texts were standardized during the next stage. The process of exploratory test analysis was carried out using the IRaMuTeQ software. (It should be noted that computer-assisted text analysis is increasingly more often used by researchers in a wide variety of fields [49-51]. Text analyses are used by scientists dealing with cultural analyses [50], linguists [49], historians [52], or those dealing with sociology [53] or anthropology [54].) The IRAMUTEQ software (French: Interface de R pour les Analyses Multidimensionnelles de Textes et de Questionnaires) is used in an increasing number of studies involving reviews of literature in various fields of science, e.g., [55,56]. IRaMuTeQ is a free open-source program that uses the analytical capabilities of the R program. It belongs to the category of IT tools in the field of data mining for extracting data from text materials, structuring them by searching for key words, phrases, sentences, and their coding in the form of numerical variables, and then their statistical processing in order to discover (and often also visualize) the relationships between them. The purpose of using the IRaMuTeQ software resources in this study is to validate the obtained text interpretations as part of a literature review.

The 12 selected texts were standardized in accordance with the requirements of the IRaMuTeQ technique [57-59]. The preparation of the text for analysis consisted in:

- Deleting any graphs, tables, figures, or footnotes in the text. Moreover, the following were also removed: the content of the header and footer, title, abstracts and keywords written in English, literature list, personal data of the author/authors and affiliation, words considered in this analysis as the so-called stop words (these are, among others: the words "introduction", "ending", "abstract", "summary" constituting the chapter titles; words "table", "drawing", "table", "fig", which were found in in the name of tables and figures, the word "source" under the figures/tables).

- The following characters were removed from the text body (a text body is a set of units to be analyzed, while a unit is a fragment or whole article): quotation mark ("), apostrophe ( $\left.{ }^{\prime}\right)$, dash (-); dollar sign (\$), percent (\%), period (...). Note: The asterisk $\left(^{*}\right)$ can only be used on command lines.

- Text-formatting elements were removed: justification, bold, italics, etc.

- It was decided that in the case of acronyms and abbreviations, the full names would not be used (i.e., they would remain in the form as used by the authors of the articles).

After the text was prepared, a preliminary analysis of the text was performed based on the classical lexicographic analysis. As a result, basic information about the average frequency of words was obtained, which were then reduced to basic lexical units, as well as, inter alia, identifying the active forms. (The program replaced all terms with their canonical form (lemmatization step): plural, singular, or verb forms with infinitives. The program then identified the terms as "active forms" (i.e., content words such as nouns, verbs, and adjectives) or as "complementary forms" (i.e., function words such as prepositions, particles, and some common verbs and adverbs), with only the former being taken into account in the analyses. Subsequently, each article was divided into text segments (ECUs) consisting of several successive lines-usually marked with punctuation-which should 
contain a minimum number of words (15 by default), and contextual units (CUs) made by combining consecutive ECUs so that each CU contains the minimum number of active forms (12 by default).) This was a necessary step to perform a similarity analysis [60]. Similarity analysis is based on graph theory. It allows analyzing the closeness and the relationship between terms (in our case, between the active forms in the Elementary Context Units-ECU). Examples of the use of similarity analysis in the research process can be found in many studies from various fields of science, e.g., [61,62]. The analysis process begins by calculating the degree of association between all active forms in pairs, and then sequentially reducing the number of associations until a linked tree without cycles is obtained. The results of the analysis are obtained in the form of a graphic tree made up of lexical items, with the central topic and the peripheral items attached to it. The closer the lexical position is to another, the closer they are to the same segment of text. Similarly, the more branched the similarity tree, the broader the link between the terms and the search object.

\section{Results}

Based on the classic lexicographic analysis, information was obtained, e.g., with average word frequency (Figure 3).

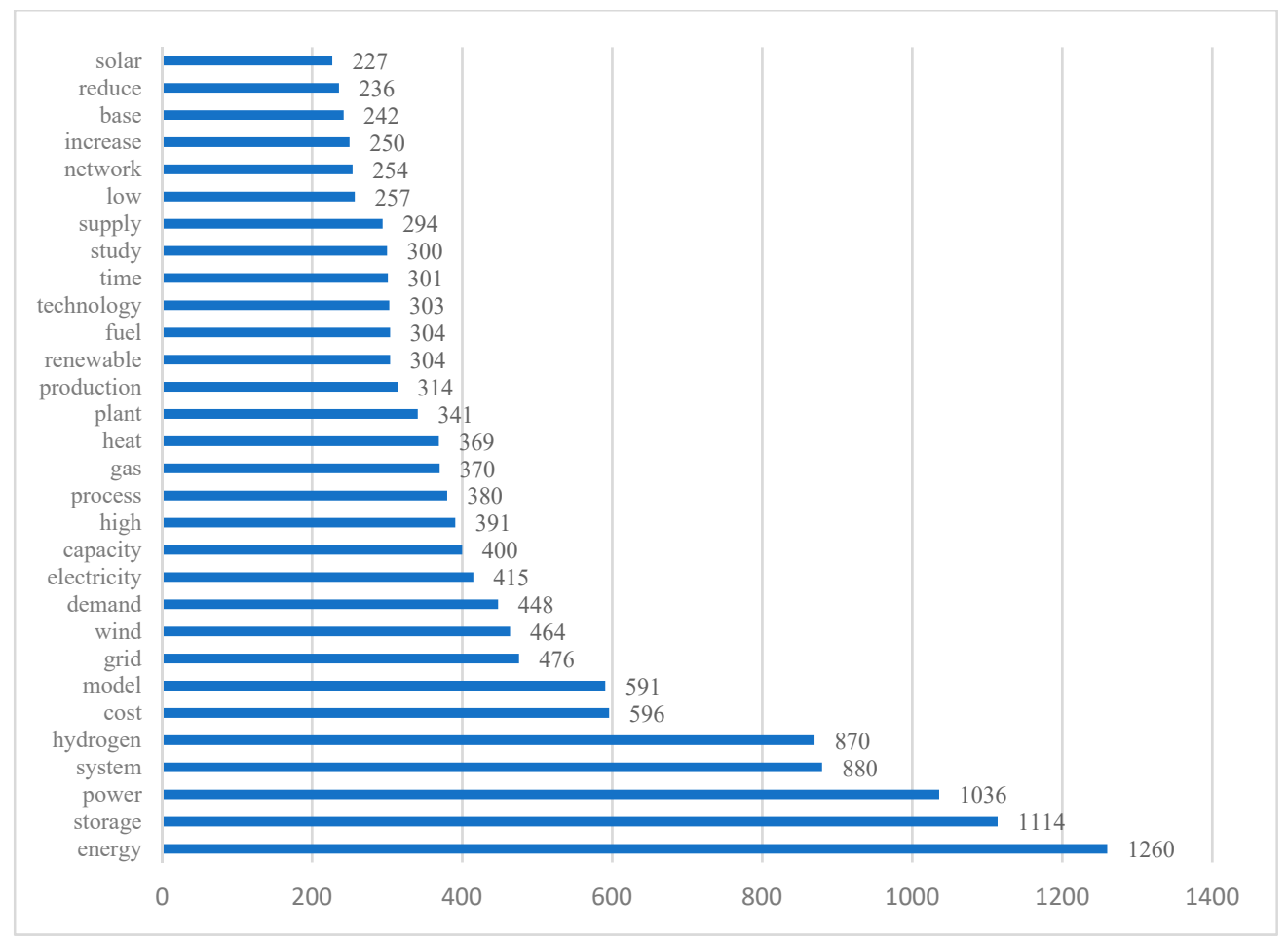

Figure 3. The thirty most common words with their respective frequencies. Source: own elaboration based on an analysis in the IRAMUTEQ software.

As previously indicated, the analysis of similarity allows the identification of cooccurring words, providing information about their interrelationships, which helps identify the structure of the text corpus. Coexistence was used as an index of similarity. There were 2438 items on the word list accepted for analysis. The repetition scale ranged from 1260 for the word "energy" to 1 for the words "abate" or "abstraction". When performing similarity analyses based on such a long list, one would expect a situation in which words characterized by a low number of repetitions would make it difficult to identify the relationship between words with a higher repetition frequency. Hence, it was decided to limit the number of words based on which the similarity analysis would be performed. A list of words was extracted, making it possible to obtain nearly half of the repetitions from the list 
of active words. Such a situation should allow finding the most important relationships between words, and the legibility of the graphic presentation of the achieved results.

Although such a research procedure is characterized by rationality, it introduced a limitation in selecting words to the analysis, which, although occurring less frequently, are significantly related to the formulated research goals. Hence, the authors, using the knowledge obtained from studying the content of pre-selected 311 articles, used the brainstorming method to make a subjective selection of words that would achieve the adopted research goal. The word set is presented in Appendix B.

To sum up, two variants of the similarity analysis were adopted. The first variant is an analysis based on the first 189 words in the active word list. Whereas, the basis of the second variant of the analysis is a list of intentionally selected words from the list of active words (the same number as in the first case), important to the research team from the point of view of the research subject.

The first variant of the analysis according to the most common of the so-called first 189 words.

The analysis on the basis of the first 189 words allowed identifying the main concept -the word "energy", around which a set of related words was created, as well as five words (i.e., "storage", "system", "power", "model", and "hydrogen") around which further sets of words were formed. It should be noted that the word "energy" coexists with the words "storage" and "system" to form practically one large set. Subsequent identified words (e.g., "power", "hydrogen", and "model") form disjoint sets of words related to the concept of "energy" but remote from that word (Figure 4).

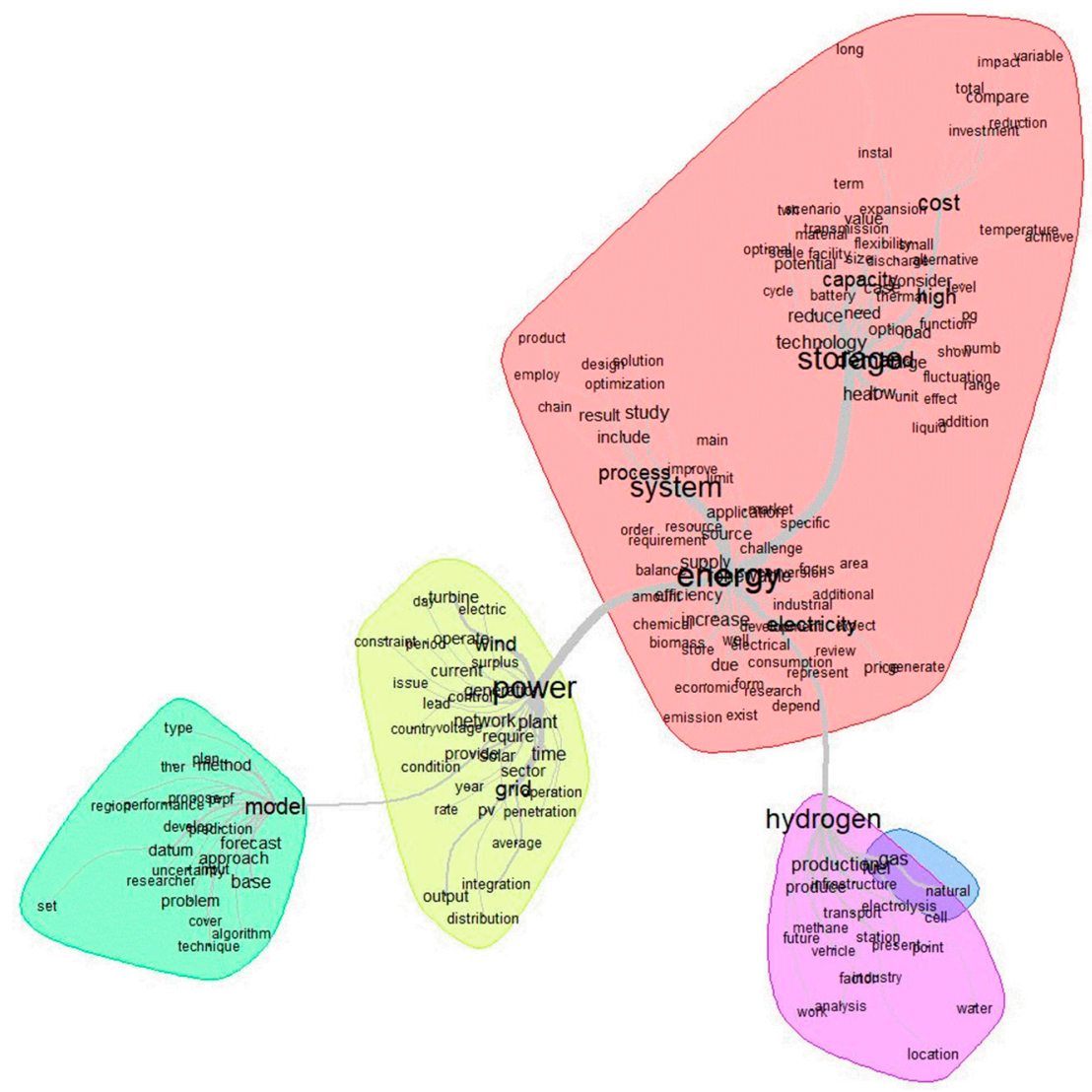

Figure 4. The results of the similarity analysis of the first 189 words. Source: own elaboration based on an analysis in the IRAMUTEQ software.

Taking into account the identified number of repetitions of individual words, the thickness of the lines between individual words and the font size of individual words, it can be indicated that the strongest co-occurrences exist between the pairs of words "energy" 
and "system" (it can be properly considered that it is one set), "energy" and "storage", as well as "energy" and "power". The coexistence between "energy" and "hydrogen" can be observed to a lesser extent.

The first set of words that is formed around the word "energy" includes, among others, the following terms: "electricity", "system", "supply", "renewable", "source", "process", "economic", "consumption", and "price". The identified words in this set (Figure 5) indicate the issues of electricity production, energy supply sources and consumption discussed in the articles. The word "energy" is closely related to the word "system", which, in turn, is strongly associated with terms that indicate research, design, and the search for solutions and energy systems.

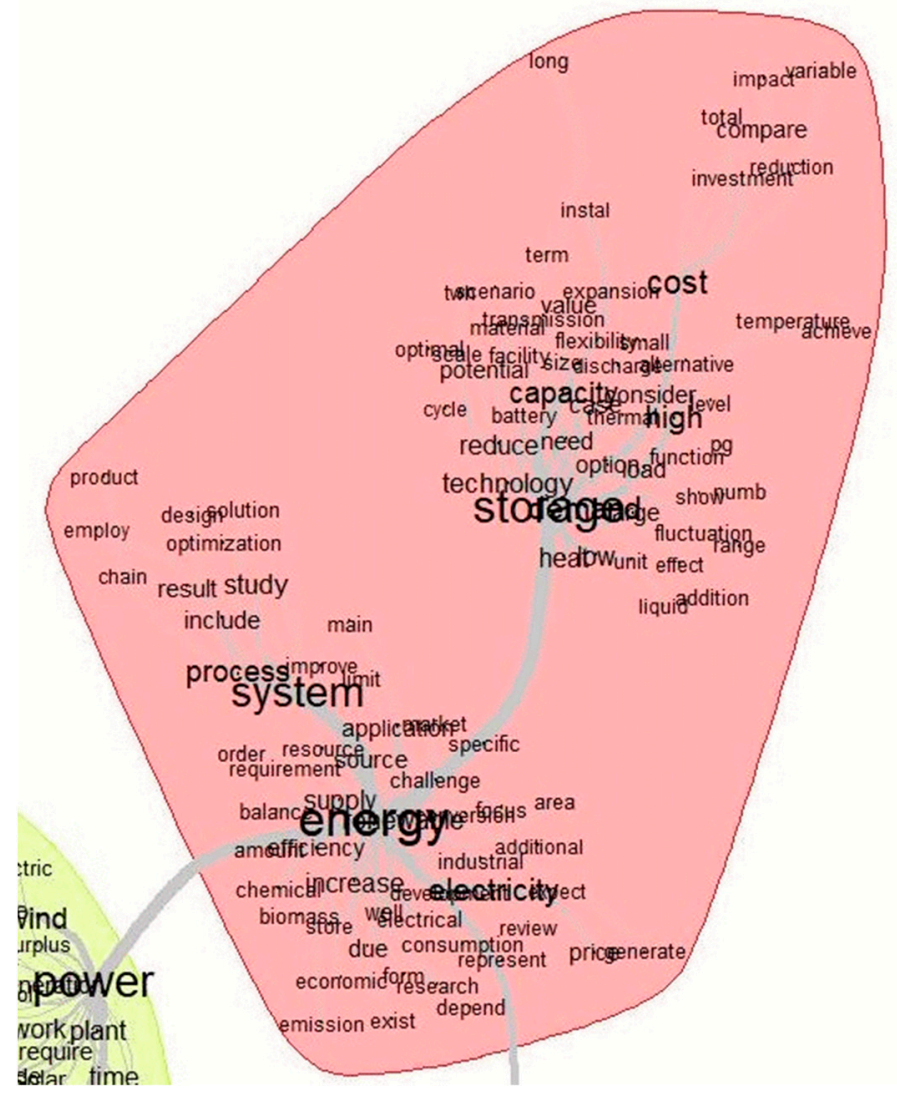

Figure 5. The set of words focused around the word "energy". Source: own elaboration based on an analysis in the IRAMUTEQ software.

Another word set, which is in fact part of the previous one, was formed around the word "storage". It is thematically similar to both the technical aspects of the storage process (technology, heat, battery, material, load, cycle, and discharge) and research in the economic dimension: "demand", "high", "capacity", "fluctuation", "cost", "investment", "compare", and "reduction".

Another set was created around the word "power" and it characterizes the technical issues of energy networks. The central word of this set concerns the words "generation", "surplus", "solar", "wind", "pv" (photovoltaic), "operation", "network", and "grid" (Figure 6). The word "model" is related quite distantly to the word "power".

The last set that was formed around the word "hydrogen" is the least related to the word "energy", as compared to the previously indicated words such as "power", "storage", or "system". This collection includes a variety of terms. The following words or phrases are closest to the central word: "production", "produce", "infrastructure", "vehicle", "transport", "ptg" (power-to-gas), and "fuel" (Figure 7). The set hydrogen is connected with the set "gas". The use of words such as "vehicle", "station", and "cell" indicates addressing the issue of hydrogen fueled vehicles. Whereas "electrolysis" and the 
very distant word "water" indicate that the issues of production technology, the so-called green hydrogen, were discussed in the research. To sum up, this set mainly covers the technical aspects of hydrogen production and transportation.

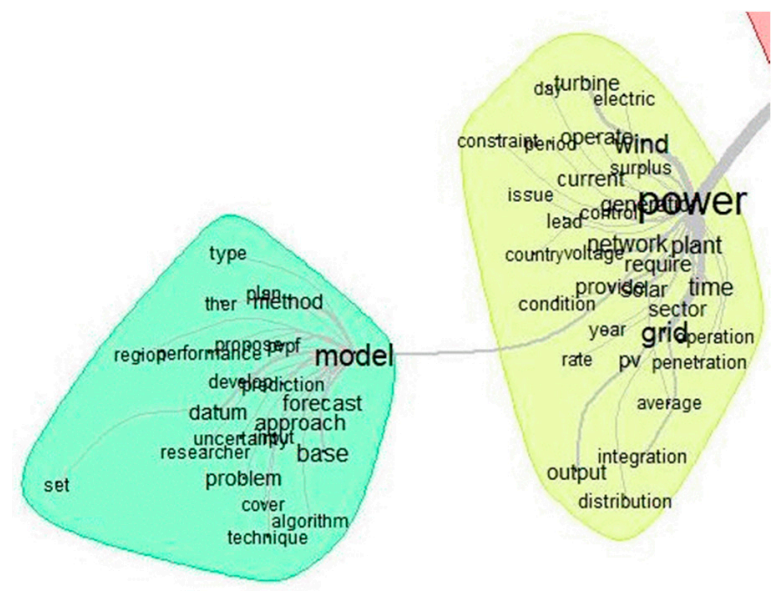

Figure 6. The set of words focused around the word "power". Source: Own elaboration based on the analysis in the IRAMUTEQ software.

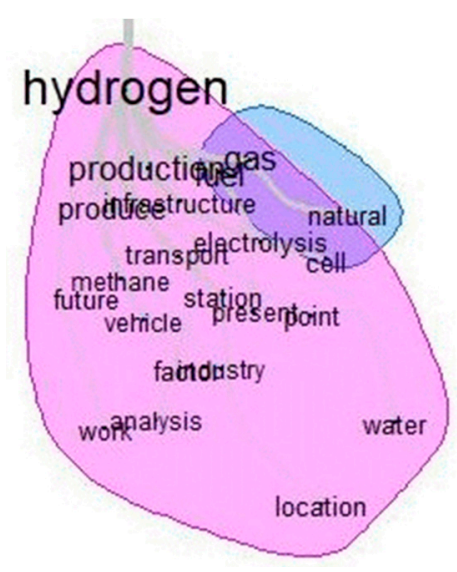

Figure 7. The set of words around the word "hydrogen". Source: Own elaboration based on the analysis in the IRAMUTEQ software.

The Second Variant of the analysis according to purposefully selected 189 words.

The second variant of the analysis for deliberately selected words practically confirms the observations presented above. The same "anchor" words were identified, around which disjoint sets of words were formed. The identified sets are linked by the word "energy", together with a set of words that accompany it (Figure 8). The analysis of the meaning of the individual words that make up the sets is similar to that presented above. The only difference is the number of words around the word "hydrogen", which in this variant of the analysis is more numerous, as it results from the research interests of the team (Figure 9). 


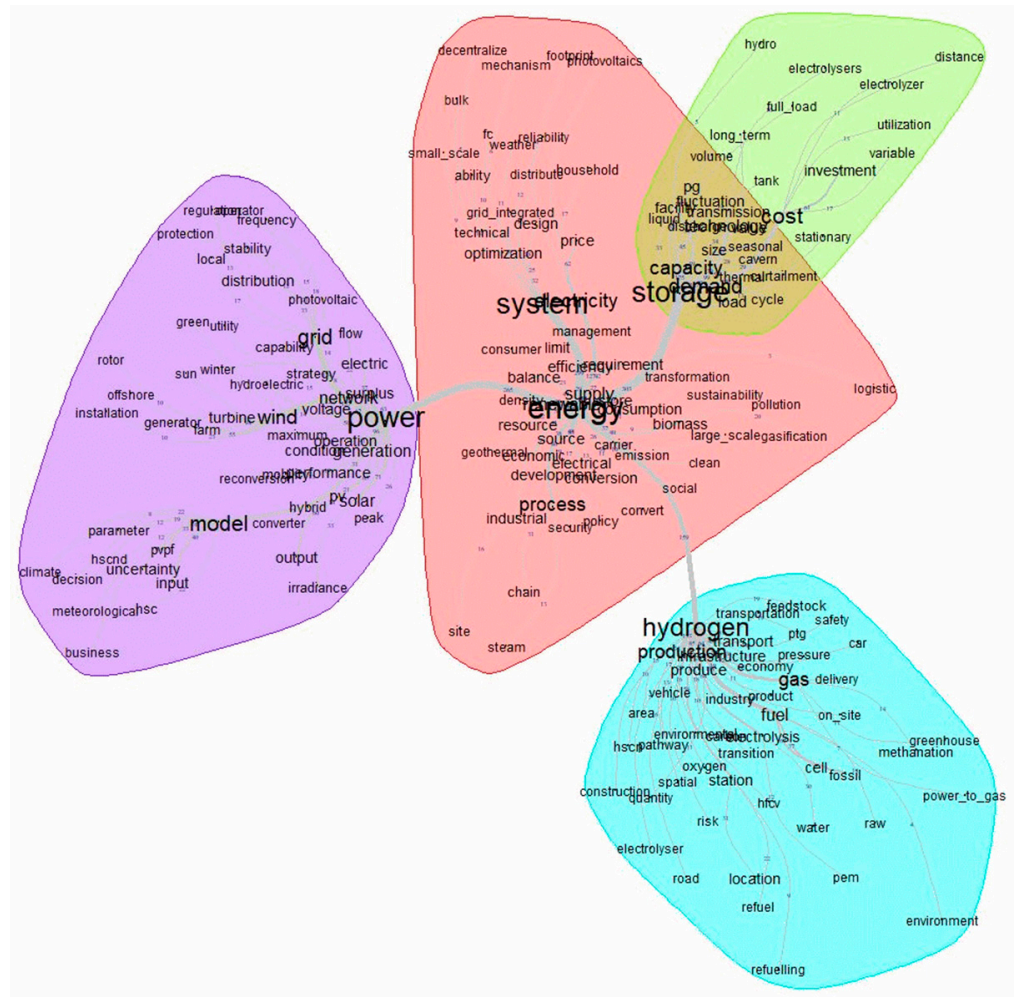

Figure 8. The results of the similarity analysis of the selected 189 words. Source: Own elaboration based on the analysis in the IRAMUTEQ software.

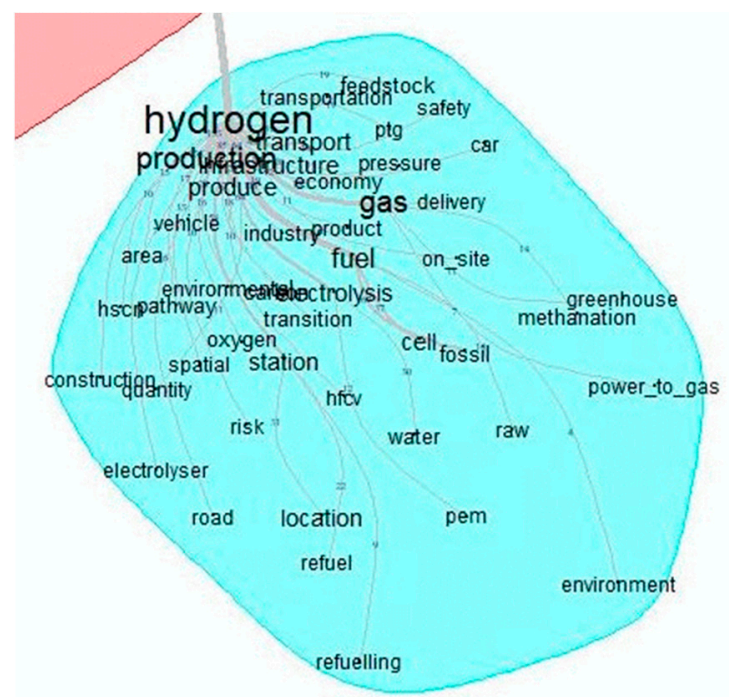

Figure 9. The set of words focused around the word "hydrogen" in the case of the analysis of intentionally selected words. Source: Own elaboration based on the analysis in the IRAMUTEQ software.

\section{Discussion}

The analysis of the above research results with the use of text-mining points to the discussion about the results achieved. The use of exploratory text analysis and the IRaMuTeQ software allowed the defining of the main thematic links in the analyzed area of research identified in selected review articles. They mainly focus on the issues of energy, energy systems, and storage. The results of the analysis with the use of text mining confirmed the subjective conclusions of the authors, obtained as a result of the traditional in-depth analysis of the full content of 12 selected review articles. 
The study of the first variant, covering the 189 most common words, indicates a large separability of the key sets focused around the words energy, storage, hydrogen, power, and model. The analysis of the layout and interrelationships of the main sets of words allows for the conclusion that the issues focused on the words system and energy are related to those regarding power, which, in turn, are directly related to modeling, but constitute a separate and distant scope of issues. The set centered around the word hydrogen with a small gas subset is quite weakly related to the energy set and the remote storage subset.

The analysis based on the frequency of occurrence and interrelationship of the first 189 words also indicates the main thematic scope of the research. In this comparison, the technical and economic approach dominates in each set created. The main elements of the energy system and the features describing the technical aspects of the process of energy production and delivery are indicated. In the area of economic concepts, the emphasis is mainly put on parameters related to the management and measurement of the production and energy supply process, e.g., capacity, requirements, order, cycle, price, and increasing its effectiveness, e.g., optimization, reduce, improve, prove, flexibility, and depend. Taking into account the identified number of repetitions, line thickness, and font size of individual words, it can be concluded that economic concepts are of a secondary nature to technical concepts. Economic concepts are more clearly emphasized in research related to energy storage, where the words cost and capacity play an important role. A separate area is the model set. It points to the great effort of researchers dealing with modeling issues mainly in the area related to the power set. The words that stand out here are forecast, production, develop, uncertainty, and plan, a fact which indicates the significant importance of research in the area of modeling power systems and the selection of appropriate research methods (method and approach). The composition of the terms around hydrogen indicates that the conducted research primarily focuses on the technical aspects of hydrogen production and transport. The issue of green hydrogen produced from renewable energy sources is not intensely reflected in articles presenting the state of knowledge in recent years. It is worth noting that in this main comparison of the most common words, there are no issues related to environmental impact, efforts aimed at the decarbonization of the economy, or linking energy production and consumption with the pursuit of climate neutrality. Although such words as, i.e., wind, pv, solar, and turbine occur in the set power; biomass and emission in the energy set; as well as the word electrolysis in the hydrogen set-the font size and the way of connection indicates their relatively marginal nature.

On the other hand, when analyzing the results of the research in the second variant of purposefully selected 189 words, it should be remembered that mainly words related to research in the area of clean (green) energy and taking into account to a greater extent the research on the use of hydrogen were included there. Thus, words related to the technical aspects of fossil energy production and distribution were removed.

In this arrangement, there are still major word sets focused around energy, power, and hydrogen. Furthermore, a separate area of connections around the word storage was selected, and by combining the sets of power and the model, the connections of research related to these concepts were emphasized. Despite the intervention in the process of selecting the most common words, this variant of the study also proves the separability of the main thematic sets; although, they were approximated.

Interestingly, this analysis setup shows that the concepts of hydrogen and renewable energy are dispersed across most sets. Thus, the terms referring to the concept of hydrogen supply chains appear both in the hydrogen (hscn-hydrogen supply chain network) and power (hsc, hscnd-hydrogen supply chain network design) sets. Moreover, in the power set, there are words indicating that research on the production of energy from renewable energy sources, including wind, solar, pv, photovoltaics, rotor, offshore, reconversion, turbine, and farm, is being carried out. The combination of the words also points to the problem of supplying power grids with energy from RES, e.g., uncertainty, sun, winter, meteorological, flow, surplus, peak, maximum, and stability, presented in the research. In the energy set, words related to energy sources and its supplies are present around this concept, including 
source, resource, biomass, geothermal, and conversion. There are also words pointing to the energy transformation process, e.g., transformation, sustainability, consumption, policy, clean, pollution, balance, and emission. The storage set, in addition to pointing to various methods of energy storage, has also distant concepts related to the production of the so-called green hydrogen, i.e., electrolysers, electrolyzer, and hydro. On the other hand, hydrogen is still the set located the furthest from the other main sets. The analysis of the words and their connections allows us to conclude that the conceptual spectrum covers the entire range of hydrogen supply chains, starting from the concepts related to the supply phase (gas, feedstock, raw, and fossil), through the production phase production, produce, electrolysis, methanation, power-to-gas, ptg, on-site, pem-proton exchange membrane electrolysis, oxygen, and water), up to the distribution phase (fuel station, cell, refuel, refueling, hfcv-hydrogen fuel cell vehicle, car, and vehicle). Research in the area of transport and infrastructure (infrastructure, transport, transportation, delivery, and road) is important.

It is worth noting that in the purposefully selected variant of words, terms such as environment, sustainability, transition, green, greenhouse, footprint, and pollution were revealed and related. It should be noted, however, that the words pointing to research aimed at accelerating the energy transformation and decarbonizing the economy or contributing to the achievement of climate neutrality, which are among the main contemporary development goals, are rare and peripheral.

\section{Conclusions}

In view of the need to limit the use of fossil fuels and apply zero or low-emission solutions, the subject of the so-called green hydrogen generated from electricity produced from renewable energy takes on particular importance. It is a new research area that integrates theoretical achievements in the field of hydrogen supply chains as well as the operation and development of power grids. The indicated common area is of great scientific and application importance.

The current research on hydrogen technologies indicates that the use of hydrogen in the economy requires the preparation of systems for its acquisition, production, and distribution, which are referred to as hydrogen supply chains. Within this area, the key issues are not only the development and selection of appropriate production technologies, suitable infrastructure, or forms of transport. It is also important to comprehensively design and manage the processes carried out in the supply, production, storage, and distribution phase of hydrogen, as well as coordinated investment in hydrogen technologies [63], so that they are effective and best support the achievement of socio-economic goals.

As a result of the scoping review, and the application of the text-mining method using the IRaMuTeQ software, which includes the analysis of the content of 12 reviews presenting the current research achievements in this field over the last three years (2016-2020), it was established that the issues related to hydrogen supply chains, including green hydrogen, are still not significantly associated with the issue of the operation of power grids. The analysis of similarity allowed the distinguishing of sets focused around the words: energy and storage, power, model, and hydrogen. In both variants of the research (the first 189 most common words and the deliberately selected 189 words), all thematic sets are disjoint. The concepts related to HSC are sporadic and diffuse. Apart from identifying them in the set gathered around the word hydrogen, they can also be found in other sets. This confirms the early stage of development of HSC research and its fragmented nature. Therefore, the conducted research, based on the WoS database, indicates that at the current stage of research, there is no common research area integrating the concept of HSC and the operation of power grids.

Moreover, the previous research mainly focuses on technical aspects, while the economic approach is rather complementary. The research conducted so far has focused primarily on the broadly understood effectiveness of the technical infrastructure for hydrogen production. Environmental, social, and legal aspects are not significantly represented in the mainstream research included in the reviewed articles. Only in the second research variant, 
the analysis of similarity showed the connections of words reflecting the main challenges concerning, inter alia, decarbonization of the economy and pollution issues. However, even in this deliberate choice of words, the indicated issues are marginal and peripheral.

The results of the conducted research fill the existing research gap. Firstly, a shortage of research was identified in the area of links between power grids and hydrogen supply chains, in particular, green hydrogen supply chains. Secondly, it indicates that the research conducted so far is of a narrow nature and focuses mainly on technical and technological aspects. There is no interdisciplinary approach to the presented issues. Thirdly, the research carried out to a small extent takes into account today's socio-economic challenges regarding energy transformation, decarbonization of the economy, and the need to achieve climate neutrality goals.

Certain limitations were identified in the research process. Due to the pioneering subject matter, they concern the applied research methodology and its limitations. In the literature on the subject regarding scoping review, it is noted that in addition to strengths, there are also weaknesses of this type of review [33]. They mainly include the inability to accurately assess the studies included in the analysis. Being aware of the mentioned weaknesses and wanting to reduce their occurrence in the scoping review, the authors of this paper focused only on the analysis of reviews presented in the WoS database. In principle, this was to guarantee the high quality of the researched content (reviewed manuscripts, indexed in WoS database). However, at the same time, it could have resulted in the omission of other important studies (peer-reviewed publications not indexed in the WoS database).

Moreover, the analysis of similarity was limited to reviews on research in the field of energy networks and hydrogen. In these articles, the teams of authors chose research examples on their own, due to the adopted goal of the publication. At this stage, the first selection of research examples was made, which resulted in referring to the examples of the latest research, as well as focusing on the dominant threads. This could have resulted in the omission of the so-called niche research.

Moreover, limitations also result from the use of the IRaMuTeQ software. There was a need to limit the number of words in the analysis so that the obtained pictures of connections were legible.

Taking into account the described research limitations, the contribution of the conducted research to the scientific achievements should be emphasized. Identifying the above gaps has allowed us to find a new research area of great cognitive, research, and application value. This is an important area due to the contribution of science in the implementation of the indicated goals of a civilized nature. On the basis of the research findings, there is a need to continue the already in-depth research of an interdisciplinary nature, covering not only technical and technological aspects, but also economic, management, environmental, and social issues.

Author Contributions: Conceptualization, M.F., K.B., M.M. and A.R.; methodology, M.F., K.B., M.M. and A.R.; software, M.F., K.B., M.M. and A.R.; validation, M.F., K.B., M.M. and A.R.; formal analysis, M.F., K.B., M.M. and A.R.; investigation, M.F., K.B., M.M., and A.R.; resources and data curation, M.F., K.B., M.M. and A.R.; writing—original draft preparation, M.F., K.B. and M.M.; writing-review and editing, M.F., K.B., M.M. and A.R.; visualization, K.B. and M.M.; supervision, M.F., K.B., M.M. and A.R.; project administration M.F., M.M. and A.R. All authors have read and agreed to the published version of the manuscript.

Funding: This research was partially funded by the National Center for Research and Development (Poland) in the framework of the H2eBuffer project. Grant Nr POIR.04.01.04-00-0040/20 (2021-2023).

Institutional Review Board Statement: Not applicable.

Informed Consent Statement: Not applicable.

Data Availability Statement: Not applicable. 
Acknowledgments: This research was supported by University of Szczecin, Institute of Management, Cukrowa Street 8, 71-004 Szczecin, Poland.

Conflicts of Interest: The authors declare no conflict of interest. 


\section{Appendix A}

Table A1. List of article titles included in the text analysis.

\begin{tabular}{|c|c|c|c|c|c|c|}
\hline No. & Author/Authors & Article Title & Journal Title & Year of Publication & Keywords & Citation Position \\
\hline 1 & Blanco, H.; Faaij, A. & $\begin{array}{l}\text { A review at the role of } \\
\text { storage in energy } \\
\text { systems with a focus on } \\
\text { Power to Gas and } \\
\text { long-term storage }\end{array}$ & $\begin{array}{c}\text { Renewable \& Sustainable } \\
\text { Energy Reviews }\end{array}$ & 2018 & $\begin{array}{l}\text { Energy storage; Energy } \\
\text { modelling; Flexibility; } \\
\text { Power to Gas. }\end{array}$ & {$[64]$} \\
\hline 2 & $\begin{array}{l}\text { Lin, R.H.; Ye, Z.Z.; } \\
\text { Wu, B.D. }\end{array}$ & $\begin{array}{l}\text { A review of hydrogen } \\
\text { station location models }\end{array}$ & $\begin{array}{l}\text { International Journal of } \\
\text { Hydrogen Energy }\end{array}$ & 2020 & $\begin{array}{c}\text { Hydrogen; Location; } \\
\text { Model; } \\
\text { Review. }\end{array}$ & [65] \\
\hline 3 & $\begin{array}{l}\text { Ausfelder, F.; Beilmann, C.; } \\
\text { Bertau, M.; Brauninger, S.; } \\
\text { Heinzel, A.; Hoer, R.; } \\
\text { Koch, W.; Mahlendorf, F.; } \\
\text { Metzelthin, A.; Peuckert, } \\
\text { M.; Plass, L.; Rauchle, K.; } \\
\text { Reuter, M.; Schaub, G.; } \\
\text { Schiebahn, S.; Schwab, E.; } \\
\text { Schuth, F.; Stolten, D.; } \\
\text { Tessmer, G.; } \\
\text { Wagemann, K.; } \\
\text { Ziegahn, K.F. }\end{array}$ & $\begin{array}{l}\text { Energy Storage as Part of } \\
\text { a Secure Energy Supply }\end{array}$ & Chembioeng Reviews & 2017 & $\begin{array}{c}\text { Energy storage technology; } \\
\text { Energy supply, } \\
\text { Optimization. }\end{array}$ & [66] \\
\hline 4 & $\begin{array}{l}\text { Maggio, G.; Nicita, A.; } \\
\text { Squadrito, G. }\end{array}$ & $\begin{array}{l}\text { How the hydrogen } \\
\text { production from RES } \\
\text { could change energy and } \\
\text { fuel markets: A review } \\
\text { of recent literature }\end{array}$ & $\begin{array}{l}\text { International Journal of } \\
\text { Hydrogen Energy }\end{array}$ & 2019 & $\begin{array}{c}\text { Hydrogen; Renewable } \\
\text { energy sources; } \\
\text { Hydrogen economy; } \\
\text { Energy market; } \\
\text { Fuel market. }\end{array}$ & [39] \\
\hline 5 & $\begin{array}{l}\text { Li, L.; Manier, H.; } \\
\text { Manier, M.A. }\end{array}$ & $\begin{array}{l}\text { Hydrogen supply chain } \\
\text { network design: An } \\
\text { optimization-oriented } \\
\text { review }\end{array}$ & $\begin{array}{c}\text { Renewable E Sustainable } \\
\text { Energy Reviews }\end{array}$ & 2019 & $\begin{array}{c}\text { Hydrogen; Supply chain; } \\
\text { Network design; } \\
\text { Optimization models. }\end{array}$ & [24] \\
\hline
\end{tabular}


Table A1. Cont.

\begin{tabular}{|c|c|c|c|c|c|c|}
\hline No. & Author/Authors & Article Title & Journal Title & Year of Publication & Keywords & Citation Position \\
\hline 6 & $\begin{array}{l}\text { Oyekale, J.; Petrollese, M.; } \\
\text { Tola, V.; Cau, G. }\end{array}$ & $\begin{array}{l}\text { Impacts of Renewable } \\
\text { Energy Resources on } \\
\text { Effectiveness of } \\
\text { Grid-Integrated Systems: } \\
\text { Succinct Review of } \\
\text { Current Challenges } \\
\text { and Potential Solution Stra }\end{array}$ & egies & 2020 & $\begin{array}{l}\text { Concentrated Solar Power; } \\
\text { Photovoltaic; Biomass And } \\
\text { Geothermal Energy; Wind } \\
\text { Energy; Renewable } \\
\text { hydrogen and fuel cells; } \\
\text { Electrochemical } \\
\text { energy storage; Thermal } \\
\text { energy storage; } \\
\text { Renewable power grid } \\
\text { technical challenges; } \\
\text { Renewable energy } \\
\text { vehicle-to-grid; } \\
\text { Artificial intelligence } \\
\text { for renewable Energy. }\end{array}$ & [27] \\
\hline 7 & $\begin{array}{l}\text { Gotz, M.; Lefebvre, J.; } \\
\text { Mors, F.; Koch, A.M.; } \\
\text { Graf, F.; Bajohr, S.; } \\
\text { Reimert, R.; Kolb, T. }\end{array}$ & $\begin{array}{c}\text { Renewable } \\
\text { Power-to-Gas: A } \\
\text { technological and } \\
\text { economic review }\end{array}$ & Renewable Energy & 2016 & $\begin{array}{c}\text { Power-to-Gas; Electrolysis } \\
\text { Methanation; SNG; } \\
\text { Renewable energy }\end{array}$ & [67] \\
\hline 9 & $\begin{array}{l}\text { Fonseca, J.D.; Camargo, } \\
\text { M.; Commenge, J.M.; } \\
\text { Falk, L.; Gil, I.D. }\end{array}$ & $\begin{array}{l}\text { Trends in design of } \\
\text { distributed energy } \\
\text { systems using hydrogen } \\
\text { as energy vector: } \\
\text { A systematic } \\
\text { literature review }\end{array}$ & $\begin{array}{l}\text { International Journal of } \\
\text { Hydrogen Energy }\end{array}$ & 2019 & $\begin{array}{c}\text { Hydrogen; Energy carrier } \\
\text { Decentralized } \\
\text { energy system; } \\
\text { Decarbonization; } \\
\text { Power-to-gas; } \\
\text { Renewable sources. }\end{array}$ & [38] \\
\hline
\end{tabular}


Table A1. Cont.

\begin{tabular}{|c|c|c|c|c|c|c|}
\hline No. & Author/Authors & Article Title & Journal Title & Year of Publication & Keywords & Citation Position \\
\hline 10 & $\begin{array}{l}\text { Ahmed, R., Sreeram, V., } \\
\text { Mishra, Y., \& Arif, M.D. }\end{array}$ & $\begin{array}{l}\text { A review and evaluation } \\
\text { of the state-of-the-art in } \\
\text { PV solar power } \\
\text { forecasting: Techniques } \\
\text { and optimization }\end{array}$ & $\begin{array}{c}\text { Renewable and Sustainable } \\
\text { Energy Reviews }\end{array}$ & 2020 & $\begin{array}{l}\text { Solar power; Forecasting } \\
\text { technique; Wavelet } \\
\text { transform } \\
\text { Deep convolutional neural } \\
\text { network; Long short term } \\
\text { memory; Optimization } \\
\text { Forecast accuracy. }\end{array}$ & [69] \\
\hline 11 & $\begin{array}{l}\text { Ahmed, S.D., Al-Ismail, } \\
\text { F.S., Shafiullah, M., } \\
\text { Al-Sulaiman, F.A., \& } \\
\text { El-Amin, I.M. }\end{array}$ & $\begin{array}{l}\text { Grid integration } \\
\text { challenges of wind } \\
\text { energy: A review }\end{array}$ & IEEE Access & 2020 & $\begin{array}{c}\text { Angular stability; Energy } \\
\text { storage system; Fault } \\
\text { ride-through capability; } \\
\text { Frequency response; } \\
\text { Grid codes; Reactive } \\
\text { power support; Voltage } \\
\text { stability; } \\
\text { Wind intermittency. }\end{array}$ & [70] \\
\hline 12 & $\begin{array}{c}\text { Zhang, C., Cheng, H., Liu, } \\
\text { L., Zhang, H., Zhang, X., \& } \\
\text { Li, G. }\end{array}$ & $\begin{array}{l}\text { Coordination planning } \\
\text { of wind farm, energy } \\
\text { storage and transmission } \\
\text { network with } \\
\text { high-penetration } \\
\text { renewable energy }\end{array}$ & $\begin{array}{l}\text { International Journal of } \\
\text { Electrical Power } \mathcal{E} \\
\text { Energy Systems }\end{array}$ & 2020 & $\begin{array}{c}\text { Integrated wind farm; } \\
\text { Energy storage system; } \\
\text { Transmission } \\
\text { expansion planning; } \\
\text { Decentralized } \\
\text { ATC algorithm; } \\
\text { Multi-regional planning; } \\
\text { High-penetration } \\
\text { renewable energy. }\end{array}$ & [71] \\
\hline
\end{tabular}




\section{Appendix B}

Table A2. Lists of the first and purposefully selected words used in the analysis of similarity.

\begin{tabular}{|c|c|c|c|}
\hline \multirow{2}{*}{ No. } & \multicolumn{2}{|c|}{ List of 189 First Words } & \multirow{2}{*}{$\begin{array}{l}\text { A List of Purposefully } \\
\text { Chosen Words }\end{array}$} \\
\hline & Words & Frequency of Occurrence & \\
\hline 1 & energy & 1260 & energy \\
\hline 2 & storage & 1114 & storage \\
\hline 3 & power & 1036 & power \\
\hline 4 & system & 880 & system \\
\hline 5 & hydrogen & 870 & hydrogen \\
\hline 6 & cost & 596 & cost \\
\hline 7 & model & 591 & model \\
\hline 8 & grid & 476 & grid \\
\hline 9 & wind & 464 & wind \\
\hline 10 & demand & 448 & demand \\
\hline 11 & electricity & 415 & electricity \\
\hline 12 & capacity & 400 & capacity \\
\hline 13 & high & 391 & process \\
\hline 14 & process & 380 & gas \\
\hline 15 & gas & 370 & production \\
\hline 16 & heat & 369 & renewable \\
\hline 17 & plant & 341 & fuel \\
\hline 18 & production & 314 & technology \\
\hline 19 & renewable & 304 & supply \\
\hline 20 & fuel & 304 & network \\
\hline 21 & technology & 303 & solar \\
\hline 22 & time & 301 & generation \\
\hline 23 & study & 300 & source \\
\hline 24 & supply & 294 & $\begin{array}{c}\text { pv } \\
\text { (Photovoltaic) }\end{array}$ \\
\hline 25 & low & 257 & efficiency \\
\hline 26 & network & 254 & produce \\
\hline 27 & increase & 250 & turbine \\
\hline 28 & base & 242 & station \\
\hline 29 & reduce & 236 & price \\
\hline 30 & solar & 227 & output \\
\hline 31 & include & 225 & load \\
\hline 32 & forecast & 220 & value \\
\hline 33 & generation & 216 & cell \\
\hline 34 & large & 201 & electrolysis \\
\hline 35 & require & 197 & operation \\
\hline 36 & datum & 196 & investment \\
\hline 37 & consider & 194 & transmission \\
\hline 38 & source & 192 & location \\
\hline 39 & approach & 191 & input \\
\hline 40 & $\mathrm{pv}$ & 185 & infrastructure \\
\hline 41 & efficiency & 183 & pg \\
\hline 42 & due & 182 & performance \\
\hline 43 & need & 181 & size \\
\hline 44 & battery & 181 & voltage \\
\hline 45 & application & 180 & economic \\
\hline 46 & produce & 177 & store \\
\hline 47 & case & 176 & limit \\
\hline 48 & result & 174 & transport \\
\hline 49 & turbine & 168 & distribution \\
\hline 50 & current & 165 & surplus \\
\hline
\end{tabular}


Table A2. Cont.

\begin{tabular}{|c|c|c|c|}
\hline \multirow{2}{*}{ No. } & \multicolumn{2}{|c|}{ List of 189 First Words } & \multirow{2}{*}{$\begin{array}{l}\text { A List of Purposefully } \\
\text { Chosen Words }\end{array}$} \\
\hline & Words & Frequency of Occurrence & \\
\hline 51 & station & 158 & optimization \\
\hline 52 & price & 158 & balance \\
\hline 53 & output & 158 & uncertainty \\
\hline 54 & option & 150 & conversion \\
\hline 55 & operate & 149 & requirement \\
\hline 56 & method & 149 & design \\
\hline 57 & compare & 147 & facility \\
\hline 58 & well & 146 & resource \\
\hline 59 & provide & 146 & industrial \\
\hline 60 & load & 146 & vehicle \\
\hline 61 & value & 145 & condition \\
\hline 62 & sector & 145 & development \\
\hline 63 & cell & 142 & consumption \\
\hline 64 & temperature & 140 & electrical \\
\hline 65 & problem & 140 & water \\
\hline 66 & electrolysis & 137 & $\begin{array}{c}\text { pvpf } \\
\text { (Photovoltaic power } \\
\text { forecasting) }\end{array}$ \\
\hline 67 & potential & 133 & fluctuation \\
\hline 68 & biomass & 133 & electric \\
\hline 69 & solution & 131 & discharge \\
\hline 70 & challenge & 129 & variable \\
\hline 71 & market & 127 & chain \\
\hline 72 & natural & 126 & area \\
\hline 73 & plan & 125 & cycle \\
\hline 74 & operation & 124 & product \\
\hline 75 & investment & 124 & emission \\
\hline 76 & integration & 124 & liquid \\
\hline 77 & control & 124 & industry \\
\hline 78 & transmission & 123 & technical \\
\hline 79 & location & 123 & strategy \\
\hline 80 & term & 122 & flow \\
\hline 81 & research & 122 & parameter \\
\hline 82 & input & 122 & environmental \\
\hline 83 & unit & 121 & transportation \\
\hline 84 & infrastructure & 121 & seasonal \\
\hline 85 & pg & 120 & maximum \\
\hline 86 & performance & 120 & farm \\
\hline 87 & show & 118 & density \\
\hline 88 & size & 117 & generator \\
\hline 89 & voltage & 116 & site \\
\hline 90 & numb & 116 & local \\
\hline 91 & economic & 116 & economy \\
\hline 92 & prediction & 115 & curtailment \\
\hline 93 & future & 114 & peak \\
\hline 94 & year & 113 & cavern \\
\hline 95 & store & 112 & fossil \\
\hline 96 & type & 111 & carrier \\
\hline 97 & penetration & 111 & oxygen \\
\hline 98 & flexibility & 111 & hybrid \\
\hline 99 & limit & 110 & decision \\
\hline 100 & lead & 108 & frequency \\
\hline 101 & amount & 108 & transition \\
\hline 102 & generate & 107 & steam \\
\hline 103 & focus & 107 & carbon \\
\hline 104 & develop & 107 & stability \\
\hline 105 & transport & 106 & pathway \\
\hline
\end{tabular}


Table A2. Cont.

\begin{tabular}{|c|c|c|c|}
\hline \multirow{2}{*}{ No. } & \multicolumn{2}{|c|}{ List of 189 First Words } & \multirow{2}{*}{$\begin{array}{l}\text { A List of Purposefully } \\
\text { Chosen Words }\end{array}$} \\
\hline & Words & Frequency of Occurrence & \\
\hline 106 & represent & 106 & feedstock \\
\hline 107 & distribution & 106 & consumer \\
\hline 108 & surplus & 105 & pressure \\
\hline 109 & optimization & 104 & mobility \\
\hline 110 & balance & 104 & long_term \\
\hline 111 & uncertainty & 103 & irradiance \\
\hline 112 & total & 103 & household \\
\hline 113 & level & 103 & volume \\
\hline 114 & depend & 103 & refuel \\
\hline 115 & conversion & 103 & policy \\
\hline 116 & function & 102 & $\begin{array}{c}\text { hsc } \\
\text { (hydrogen supply chain) }\end{array}$ \\
\hline 117 & scale & 101 & $\begin{array}{l}\text { convert } \\
\text { hscn }\end{array}$ \\
\hline 118 & material & 101 & $\begin{array}{c}\text { (Hydrogen supply chain } \\
\text { network) }\end{array}$ \\
\hline 119 & thermal & 100 & capability \\
\hline 120 & requirement & 100 & ability \\
\hline 121 & design & 100 & weather \\
\hline 122 & chemical & 100 & ptg \\
\hline 123 & propose & 99 & operator \\
\hline 124 & facility & 99 & management \\
\hline 125 & resource & 98 & gasification \\
\hline 126 & range & 98 & car \\
\hline 127 & industrial & 96 & security \\
\hline 128 & exist & 96 & distribute \\
\hline 129 & vehicle & 95 & utilization \\
\hline 130 & condition & 95 & $\begin{array}{l}\text { large_scale } \\
\text { hscnd }\end{array}$ \\
\hline 131 & development & 94 & $\begin{array}{l}\text { (Hydrogen supply chain } \\
\text { network design) }\end{array}$ \\
\hline 132 & consumption & 94 & grid_integrated \\
\hline 133 & factor & 93 & safety \\
\hline 134 & electrical & 93 & protection \\
\hline 135 & water & 92 & reliability \\
\hline 136 & small & 92 & quantity \\
\hline 137 & pvpf & 92 & installation \\
\hline 138 & optimal & 92 & raw \\
\hline 139 & main & 91 & construction \\
\hline 140 & fluctuation & 89 & tank \\
\hline 141 & electric & 89 & stationary \\
\hline 142 & alternative & 89 & spatial \\
\hline 143 & scenario & 88 & pem \\
\hline 144 & form & 88 & electrolyzer \\
\hline 145 & achieve & 88 & rotor \\
\hline 146 & long & 87 & decentralize \\
\hline 147 & instal & 87 & risk \\
\hline 148 & discharge & 87 & converter \\
\hline 149 & variable & 86 & climate \\
\hline 150 & technique & 85 & regulation \\
\hline 100 & lead & 108 & frequency \\
\hline 101 & amount & 108 & transition \\
\hline 102 & generate & 107 & steam \\
\hline 103 & focus & 107 & carbon \\
\hline 104 & develop & 107 & stability \\
\hline 105 & transport & 106 & pathway \\
\hline
\end{tabular}


Table A2. Cont.

\begin{tabular}{|c|c|c|c|}
\hline \multirow{2}{*}{ No. } & \multicolumn{2}{|c|}{ List of 189 First Words } & \multirow{2}{*}{$\begin{array}{l}\text { A List of Purposefully } \\
\text { Chosen Words }\end{array}$} \\
\hline & Words & Frequency of Occurrence & \\
\hline 106 & represent & 106 & feedstock \\
\hline 107 & distribution & 106 & consumer \\
\hline 108 & surplus & 105 & pressure \\
\hline 109 & optimization & 104 & mobility \\
\hline 110 & balance & 104 & long_term \\
\hline 111 & uncertainty & 103 & irradiance \\
\hline 112 & total & 103 & household \\
\hline 113 & level & 103 & volume \\
\hline 114 & depend & 103 & refuel \\
\hline 115 & conversion & 103 & policy \\
\hline 116 & function & 102 & $\begin{array}{c}\text { hsc } \\
\text { (hydrogen supply chain) }\end{array}$ \\
\hline 117 & scale & 101 & $\begin{array}{l}\text { convert } \\
\text { hscn }\end{array}$ \\
\hline 118 & material & 101 & $\begin{array}{c}\text { (Hydrogen supply chain } \\
\text { network) }\end{array}$ \\
\hline 119 & thermal & 100 & capability \\
\hline 120 & requirement & 100 & ability \\
\hline 121 & design & 100 & weather \\
\hline 122 & chemical & 100 & ptg \\
\hline 123 & propose & 99 & operator \\
\hline 124 & facility & 99 & management \\
\hline 125 & resource & 98 & gasification \\
\hline 126 & range & 98 & car \\
\hline 127 & industrial & 96 & security \\
\hline 128 & exist & 96 & distribute \\
\hline 129 & vehicle & 95 & utilization \\
\hline 130 & condition & 95 & $\begin{array}{l}\text { large_scale } \\
\text { hscnd }\end{array}$ \\
\hline 131 & development & 94 & $\begin{array}{l}\text { (Hydrogen supply chain } \\
\text { network design) }\end{array}$ \\
\hline 132 & consumption & 94 & grid_integrated \\
\hline 133 & factor & 93 & safety \\
\hline 134 & electrical & 93 & protection \\
\hline 135 & water & 92 & reliability \\
\hline 136 & small & 92 & quantity \\
\hline 137 & pvpf & 92 & installation \\
\hline 138 & optimal & 92 & raw \\
\hline 139 & main & 91 & construction \\
\hline 140 & fluctuation & 89 & tank \\
\hline 141 & electric & 89 & stationary \\
\hline 142 & alternative & 89 & spatial \\
\hline 143 & scenario & 88 & pem \\
\hline 144 & form & 88 & electrolyzer \\
\hline 145 & achieve & 88 & rotor \\
\hline 146 & long & 87 & decentralize \\
\hline 147 & instal & 87 & risk \\
\hline 148 & discharge & 87 & converter \\
\hline 149 & variable & 86 & climate \\
\hline 150 & technique & 85 & regulation \\
\hline 151 & point & 85 & photovoltaic \\
\hline 152 & improve & 85 & distance \\
\hline 153 & addition & 85 & footprint \\
\hline 154 & order & 84 & environment \\
\hline 155 & methane & 84 & delivery \\
\hline
\end{tabular}


Table A2. Cont.

\begin{tabular}{|c|c|c|c|}
\hline \multirow{2}{*}{ No. } & \multicolumn{2}{|c|}{ List of 189 First Words } & \multirow{2}{*}{$\begin{array}{l}\text { A List of Purposefully } \\
\text { Chosen Words }\end{array}$} \\
\hline & Words & Frequency of Occurrence & \\
\hline 156 & chain & 83 & clean \\
\hline 157 & algorithm & 83 & transformation \\
\hline 158 & reduction & 82 & sustainability \\
\hline 159 & ther & 81 & power_to_gas \\
\hline 160 & expansion & 81 & utility \\
\hline 161 & day & 81 & mechanism \\
\hline 162 & cover & 81 & electrolysers \\
\hline 163 & area & 81 & on_site \\
\hline 164 & review & 80 & small_scale \\
\hline 165 & cycle & 80 & green \\
\hline 166 & twh & 79 & electrolyser \\
\hline 167 & specific & 79 & photovoltaics \\
\hline 168 & effect & 79 & hydro \\
\hline 169 & constraint & 79 & greenhouse \\
\hline 170 & impact & 78 & pollution \\
\hline 171 & average & 78 & biomass \\
\hline 172 & analysis & 78 & thermal \\
\hline 173 & rate & 77 & methantion \\
\hline 174 & product & 77 & geothermal \\
\hline 175 & emission & 77 & social \\
\hline 176 & set & 76 & reconversion \\
\hline 177 & country & 76 & $\begin{array}{c}\text { hfcv } \\
\text { (hydrogen fuel cell vehicle) }\end{array}$ \\
\hline 178 & work & 75 & meteorological \\
\hline 179 & liquid & 75 & hydroelectric \\
\hline 180 & expect & 75 & $\begin{array}{c}\mathrm{fc} \\
\text { (Fuel Cells) }\end{array}$ \\
\hline 181 & additional & 75 & full_load \\
\hline 182 & industry & 74 & business \\
\hline 183 & region & 73 & winter \\
\hline 184 & employ & 73 & refuelling \\
\hline 185 & role & 72 & offshore \\
\hline 186 & researcher & 72 & logistic \\
\hline 187 & present & 72 & bulk \\
\hline 188 & period & 72 & sun \\
\hline 189 & issue & 72 & road \\
\hline
\end{tabular}

\section{References}

1. Lu, Y.; Khan, Z.A.; Alvarez-Alvarado, M.S.; Zhang, Y.; Huang, Z.; Imran, M. A Critical Review of Sustainable Energy Policies for the Promotion of Renewable Energy Sources. Sustainability 2020, 12, 5078. [CrossRef]

2. Costantini, V.; Crespi, F. Public policies for a sustainable energy sector: Regulation, diversity and fostering of innovation. J. Evol. Econ. 2010, 23, 401-429. [CrossRef]

3. Hnatyshyn, M. Decomposition analysis of the impact of economic growth on ammonia and nitrogen oxides emissions in the European Union. J. Int. Stud. 2018, 11, 201-209. [CrossRef]

4. Papadis, E.; Tsatsaronis, G. Challenges in the decarbonization of the energy sector. Energy 2020, 205, 118025. [CrossRef]

5. Shindina, T.; Streimikis, J.; Sukhareva, Y.; Nawrot, Ł. Social and Economic Properties of the Energy Markets. Econ. Sociol. 2018, 11, 334-344. [CrossRef]

6. Streimikiene, D. Ranking of Baltic States on progress towards the main energy security goals of European energy union strategy. J. Int. Stud. 2020, 13, 24-37. [CrossRef]

7. Stavytskyy, A.; Kharlamova, G.; Giedraitis, V.; Šumskis, V. Estimating the interrelation between energy security and macroeconomic factors in European countries. J. Int. Stud. 2018, 11, 217-238. [CrossRef]

8. European Commission. A European Green Deal. Striving to be the First Climate-Neutral Continent. Available online: https: / / ec.europa.eu/info/strategy/priorities-2019-2024/european-green-deal_en (accessed on 22 October 2021).

9. Štreimikienè, D. Externalities of power generation in Visegrad countries and their integration through support of renewables. Econ. Sociol. 2021, 14, 89-102. [CrossRef] 
10. Tvaronavičienė, M.; Prakapienè, D.; Garškaitè-Milvydienė, K.; Prakapas, R.; Nawrot, Ł. Energy Efficiency in the Long-Run in the Selected European Countries. Econ. Sociol. 2018, 11, 245-254. [CrossRef]

11. Wach, K.; Głodowska, A.; Maciejewski, M.; Sieja, M. Europeanization Processes of the EU Energy Policy in Visegrad Countries in the Years 2005-2018. Energies 2021, 14, 1802. [CrossRef]

12. Pach-Gurgul, A.; Ulbrych, M. Progress of the V4 Countries towards the EU's Energy and Climate Targets in the Context of Energy Security Improvement. Entrep. Bus. Econ. Rev. 2019, 7, 175-197. [CrossRef]

13. Mańkowska, M.; Pluciński, M.; Kotowska, I. Biomass Sea-Based Supply Chains and the Secondary Ports in the Era of Decarbonization. Energies 2021, 14, 1796. [CrossRef]

14. Panwar, N.; Kaushik, S.; Kothari, S. Role of renewable energy sources in environmental protection: A review. Renew. Sustain. Energy Rev. 2011, 15, 1513-1524. [CrossRef]

15. Mariyakhan, K.; Mohamued, E.A.; Khan, M.A.; Popp, J.; Oláh, J. Does the Level of Absorptive Capacity Matter for Carbon Intensity? Evidence from the USA and China. Energies 2020, 13, 407. [CrossRef]

16. Pei, J.; Yao, J.; Liu, R.; Zeng, D.; Sun, P.; Zhang, H.; Liu, Y. Characteristic Analysis and Risk Assessment for Voltage-Frequency Coupled Transient Instability of Large-Scale Grid-Connected Renewable Energy Plants During LVRT. IEEE Trans. Ind. Electron. 2020, 67, 5515-5530. [CrossRef]

17. Yap, K.Y.; Sarimuthu, C.R.; Lim, J.M.-Y. Virtual Inertia-Based Inverters for Mitigating Frequency Instability in Grid-Connected Renewable Energy System: A Review. Appl. Sci. 2019, 9, 5300. [CrossRef]

18. European Commission. Communication from the Commission to the European Parliament, the Council, the European Economic and Social Committee and the Committee of the Regions A Hydrogen Strategy for a Climate-Neutral Europe COM/2020/301 final. 2020. Available online: https:/ /eur-lex.europa.eu/legal-content/EN/TXT/?uri=CELEX:52020DC0301 (accessed on 4 November 2021).

19. Frankowska, M.; Rzeczycki, A. Hydrogen Supply Chains-New Perspective for Stabilizing Power Grid. Int. J. Latest Res. Eng. Technol. 2020, 6, 1-7.

20. Svazas, M.; Navickas, V.; Krajnakova, E.; Nakonieczny, J. Sustainable supply chain of the biomass cluster as a factor for preservation and enhancement of forests. J. Int. Stud. 2019, 12, 309-321. [CrossRef]

21. Ren, J.-Z.; Tan, S.-Y.; Dong, L.-C. The Assessment of Hydrogen Energy Systems for Fuel Cell Vehicles Using Principal Component Analysis and Cluster Analysis. ISRN Chem. Eng. 2012, 2012, 1-8. [CrossRef]

22. Kim, J.; Lee, Y.; Moon, I. Optimization of a hydrogen supply chain under demand uncertainty. Int. J. Hydrogen Energy 2008, 33, 4715-4729. [CrossRef]

23. Nunes, P.; Oliveira, F.; Hamacher, S.; Almansoori, A. Design of a hydrogen supply chain with uncertainty. Int. J. Hydrogen Energy 2015, 40, 16408-16418. [CrossRef]

24. Li, L.; Manier, H.; Manier, M.-A. Hydrogen supply chain network design: An optimization-oriented review. Renew. Sustain. Energy Rev. 2019, 103, 342-360. [CrossRef]

25. Kim, M.; Kim, J. Optimization model for the design and analysis of an integrated renewable hydrogen supply (IRHS) system: Application to Korea's hydrogen economy. Int. J. Hydrogen Energy 2016, 41, 16613-16626. [CrossRef]

26. De-León Almaraz, S.; Azzaro-Pantel, C.; Montastruc, L.; Domenech, S. Hydrogen supply chain optimization for deployment scenarios in the Midi-Pyrénées region, France. Int. J. Hydrogen Energy 2014, 39, 11831-11845. [CrossRef]

27. Oyekale, J.; Petrollese, M.; Tola, V.; Cau, G. Impacts of Renewable Energy Resources on Effectiveness of Grid-Integrated Systems: Succinct Review of Current Challenges and Potential Solution Strategies. Energies 2020, 13, 4856. [CrossRef]

28. Ogumerem, G.S.; Kim, C.; Kesisoglou, I.; Diangelakis, N.A.; Pistikopoulos, E.N. A multi-objective optimization for the design and operation of a hydrogen network for transportation fuel. Chem. Eng. Res. Des. 2018, 131, 279-292. [CrossRef]

29. Won, W.; Kwon, H.; Han, J.; Kim, J. Design and operation of renewable energy sources based hydrogen supply system: Technology integration and optimization. Renew. Energy 2017, 103, 226-238. [CrossRef]

30. Dominković, D.F.; Bačeković, I.; Pedersen, A.S.; Krajačić, G. The future of transportation in sustainable energy systems: Opportunities and barriers in a clean energy transition. Renew. Sustain. Energy Rev. 2018, 82, 1823-1838.

31. Acar, C.; Dincer, I. Review and evaluation of hydrogen production options for better environment. J. Clean. Prod. 2019, 218, 835-849. [CrossRef]

32. Hosseini, S.E.; Wahid, M.A. Hydrogen production from renewable and sustainable energy resources: Promising green energy carrier for clean development. Renew. Sustain. Energy Rev. 2016, 57, 850-866. [CrossRef]

33. Nikolaidis, P.; Poullikkas, A. A comparative overview of hydrogen production processes. Renew. Sustain. Energy Rev. 2017, 67, 597-611. [CrossRef]

34. Reuß, M.; Grube, T.; Robinius, M.; Preuster, P.; Wasserscheid, P.; Stolten, D. Seasonal storage and alternative carriers: A flexible hydrogen supply chain model. Appl. Energy 2017, 200, 290-302. [CrossRef]

35. Alazemi, J.; Andrews, J. Automotive hydrogen fuelling stations: An international review. Renew. Sustain. Energy Rev. 2015, 48, 483-499. [CrossRef]

36. Lahnaoui, A.; Wulf, C.; Heinrichs, H.; Dalmazzone, D. Optimizing hydrogen transportation system for mobility by mini-mizing the cost of transportation via compressed gas truck in North Rhine-Westphalia. Appl. Energy 2018, 223, 317-328. [CrossRef]

37. Drożdż, W.; Elżanowski, F.; Dowejko, J.; Brożyński, B. Hydrogen Technology on the Polish Electromobility Market. Legal, Economic, and Social Aspects. Energies 2021, 14, 2357. [CrossRef] 
38. Fonseca, J.D.; Camargo, M.; Commenge, J.-M.; Falk, L.; Gil, I.D. Trends in design of distributed energy systems using hydrogen as energy vector: A systematic literature review. Int. J. Hydrogen Energy 2019, 44, 9486-9504. [CrossRef]

39. Maggio, G.; Nicita, A.; Squadrito, G. How the hydrogen production from RES could change energy and fuel markets: A review of recent literature. Int. J. Hydrogen Energy 2019, 44, 11371-11384. [CrossRef]

40. Cooper, S.; Cant, R.; Kelly, M.; Levett-Jones, T.; McKenna, L.; Seaton, P.; Bogossian, F. An Evidence-Based Checklist for Im-proving Scoping Review Quality. Clin. Nurs. Res. 2021, 30, 230-240. [CrossRef]

41. Pham, M.T.; Rajić, A.; Greig, J.D.; Sargeant, J.M.; Papadopoulos, A.; Mcewen, S.A. A scoping review of scoping reviews: Ad-vancing the approach and enhancing the consistency. Res. Synth. Methods 2014, 5, 371-385. [CrossRef]

42. Peterson, J.; Pearce, P.F.; Ferguson, L.A.; Langford, C.A. Understanding scoping reviews: Definition, purpose, and process. J. Am. Assoc. Nurse Pract. 2017, 29, 12-16. [CrossRef]

43. Wiklicki, M. Metodyka Przeglądu Zakresu Literatury (scoping review). In Wspótczesne Zarzadzanie-Koncepcje I Wyzwania; Oficyna Wydawnicza SGH: Warszawa, Poland, 2020; pp. 53-68.

44. Colquhoun, H.L.; Levac, D.; O’Brien, K.K.; Straus, S.; Tricco, A.C.; Perrier, L.; Kastner, M.; Moher, D. Scoping reviews: Time for clarity in definition, methods, and reporting. J. Clin. Epidemiol. 2014, 67, 1291-1294. [CrossRef]

45. Munn, Z.; Peters, M.D.J.; Stern, C.; Tufanaru, C.; McArthur, A.; Aromataris, E. Systematic review or scoping review? Guidance for authors when choosing between a systematic or scoping review approach. BMC Med. Res. Methodol. 2018, 18, 143. [CrossRef]

46. Tricco, A.C.; Lillie, E.; Zarin, W.; O’Brien, K.; Colquhoun, H.; Kastner, M.; Levac, D.; Ng, C.; Sharpe, J.P.; Wilson, K.; et al. A scoping review on the conduct and reporting of scoping reviews. BMC Med. Res. Methodol. 2016, 16, 1-10. [CrossRef]

47. Hearst, M.A. Untangling Text Data Mining. In Proceedings of the 37th Annual Meeting of the Association for Computational Linguistics, College Park, MD, USA, 20-26 June 1999; pp. 3-10.

48. Grabowski, M. Opis procedury pozyskania i ujednolicenia danych w eksploracyjnej analizie artykułów naukowych. Zesz. Nauk. Ekon. Krakowie 2010, 838, 19-33.

49. Lieberman, E.; Michel, J.-B.; Jackson, J.; Tang, T.; Nowak, M.A. Quantifying the evolutionary dynamics of language. Nature 2007, 449, 713-716. [CrossRef]

50. Michel, M.J.; Shen, Y.K.; Aiden, A.P.; Veres, A.; Gray, M.K.; The Google Books Team; Pickett, J.P.; Hoiberg, D.; Clancy, D.; Norvig, P.; et al. Quantitative Analysis of Culture Using Millions of Digitized Books. Science 2011, 331, 176-182. [CrossRef]

51. Taboada, M.; Brooke, J.; Tofiloski, M.; Voll, K.; Stede, M. Lexicon-Based Methods for Sentiment Analysis. Comput. Linguist. 2011, 37, 267-307. [CrossRef]

52. Pagel, M.; Atkinson, Q.; Meade, A. Frequency of word-use predicts rates of lexical evolution throughout Indo-European history. Nature 2007, 449, 717-720. [CrossRef]

53. Niedbalski, J. Metody i Techniki Odkrywania Wiedzy. Narzędzia CAQDAS w Procesie Analiz Danych Jakościowych; Wydawnictwo Uniwersytetu Łódzkiego: Łódź, Poland, 2014.

54. DeWall, N.C.; Pond, R.S., Jr.; Campbell, W.K.; Twenge, J.M. Tuning in to Psychological Change: Linguistic Markers of Psychological Traits and Emotions over Time in Popular U.S. Song Lyrics. Psychol. Aesthet. Creat. Arts 2011, 5, 200-207. [CrossRef]

55. Martins, D.G. O estado da arte da capacidade institucional: Uma revisão sistemática da literatura em língua portuguesa. Cad. Ebape. Br. 2021, 19, 165-189. [CrossRef]

56. Zorgetto-Pinheiro, V.A.; De Vasconcelos, A.M.; Pinheiro, R.S.; Bogo, D.; Silva, I.S. Experimental Models in Rheumatoid Ar-thritis: A Systematic Review using the IRAMUTEQ software. Int. J. Innov. Educ. Res. 2020, 8, 119-134. [CrossRef]

57. Chaves, M.M.N.; dos Santos, A.P.R.; dos Santosa, N.P.; Larocca, L.M. Use of the Software IRAMUTEQ in Qualitative Research: An Experience Report. In Studies in Systems, Decision and Control; Springer International Publishing: New York, NY, USA, 2017; Volume 71, pp. 39-48, ISBN 9783319432700.

58. Ramos, M.G.; Marina, V.; Amaral-rosa, M.P. Contributions of IRAMUTEQ software for Discursive Textual Analysis. In Proceedings of the the 3rd World Conference on Qualitative Research, Lisbon, Portugal, 17-19 October 2018; Volume 2, pp. 13-14.

59. Ramos, M.G.; do Rosário Lima, V.M.; Amaral-Rosa, M.P. IRAMUTEQ Software and Discursive Textual Analysis: Interpretive Possibilities. In Advances in Intelligent Systems and Computing; Springer Verlag: Berlin/Heidelberg, Germany, 2019; Volume 861, pp. 58-72.

60. Flament, C.; Degenne, A.; Verges, P. Similarity Analysis; Maison des Sciences de l'Homme: Paris, France, 1971.

61. Da Silva, A.M.B.; Enumo, S.R.F. Description and analysis of psychological intervention with dancers by the software IRA-MUTEQ. Temas Psicol. 2017, 25, 595-611. [CrossRef]

62. Delattre, L.; Chanel, O.; Livenais, C.; Napoléone, C. Combining discourse analyses to enrich theory: The case of local land-use policies in South Eastern France. Ecol. Econ. 2015, 113, 60-75. [CrossRef]

63. Gu, C.; Zhang, Y.; Wang, J.; Li, Q. Joint planning of electrical storage and gas storage in power-gas distribution network considering high-penetration electric vehicle and gas vehicle. Appl. Energy 2021, 301, 117447. [CrossRef]

64. Blanco, H.; Faaij, A. A review at the role of storage in energy systems with a focus on Power to Gas and long-term storage. Renew. Sustain. Energy Rev. 2018, 81, 1049-1086. [CrossRef]

65. Lin, R.-H.; Ye, Z.-Z.; Wu, B.-D. A review of hydrogen station location models. Int. J. Hydrogen Energy 2020, 45, 20176-20183. [CrossRef]

66. Ausfelder, F.; Beilmann, C.; Bertau, M.; Bräuninger, S.; Heinzel, A.; Hoer, R.; Koch, W.; Mahlendorf, F.; Metzelthin, A.; Peuckert, M.; et al. Energy Storage as Part of a Secure Energy Supply. ChemBioEng Rev. 2017, 4, 144-210. [CrossRef] 
67. Götz, M.; Lefebvre, J.; Mörs, F.; McDaniel Koch, A.; Graf, F.; Bajohr, S.; Reimert, R.; Kolb, T. Renewable Power-to-Gas: A technological and economic review. Renew. Energy 2016, 85, 1371-1390. [CrossRef]

68. Maryam, S. Review of modelling approaches used in the HSC context for the UK. Int. J. Hydrogen Energy 2017, 42, 24927-24938. [CrossRef]

69. Ahmed, R.; Sreeram, V.; Mishra, Y.; Arif, M. A review and evaluation of the state-of-the-art in PV solar power forecasting: Techniques and optimization. Renew. Sustain. Energy Rev. 2020, 124, 109792. [CrossRef]

70. Ahmed, S.D.; Al-Ismail, F.S.M.; Shafiullah; Al-Sulaiman, F.A.; El-Amin, I.M. Grid Integration Challenges of Wind Energy: A Review. IEEE Access 2020, 8, 10857-10878. [CrossRef]

71. Zhang, C.; Cheng, H.; Liu, L.; Zhang, H.; Zhang, X.; Li, G. Coordination planning of wind farm, energy storage and trans-mission network with high-penetration renewable energy. Int. J. Electr. Power Energy Syst. 2020, 120, 105944. [CrossRef] 